\title{
Antecedents of capital structure and firm performance: evidence from G-7 countries
}

\author{
Muhammad Riaz, Shu Jinghong and Muhammad Nadeem Akhtar \\ School of International Trade and Economics, \\ University of International Trade and Economics, Beijing, China
}

\begin{abstract}
Purpose - The main goal of this study is to analyze how monetary debt effects firm behavior of 167 registered manufacturing companies in G-7 countries.

Design/methodology/approach - The sample of the present study is taken from the listed firms in G-7 countries. For the building companies, the yearly financial statements of 2007-2018 have been taken from world stock exchange and Thomson Reuters Data Stream. In this study, regression analysis are directed with panel data over the period of 2007-2018 using ordinary least square summary statistics, correlation matrix and generalized method moments. Data were analyzed by employing E Views and Stata 13 software.

Findings - The significant findings of the current study indicated that fixed assets, tangible assets, taxes, net cash and profitability have positive association with debt level.

Research limitations/implications - The current work include only registered manufacturing firms in G-7 countries. Moreover, ownership types are not accounted for in this study.

Practical implications - The current analysis is an empirical investigation of antecedents of debt regarding G-7 countries with up-to-date data. Various regression inquires have been made to design the models using different measures of debt and measure of firm performance indicators. These works will assist G-7 countries firms to know the effects of identified factors on time raising debt level.

Originality/value - The current work has been finalized using genuine data of yearly reports and database. This study incorporated antecedents of debt, which have limited discourse in prior literature. Furthermore, this study explores the connection between debt level and firm performance of G-7 countries.
\end{abstract}

Keywords Capital structure, Debt level, Firm performance, G-7

Paper type Research paper

\author{
List of abbreviations \\ OLS Ordinary least square \\ GMM Generalized method of moments \\ TD Total debt
}

(C) Muhammad Riaz, Shu Jinghong and Muhammad Nadeem Akhtar. Published in Journal of Money and Business. Published by Emerald Publishing Limited. This article is published under the Creative Commons Attribution (CC BY 4.0) licence. Anyone may reproduce, distribute, translate and create derivative works of this article (for both commercial and non-commercial purposes), subject to full attribution to the original publication and authors. The full terms of this licence may be seen at http:// creativecommons.org/licences/by/4.0/legalcode

The author appreciates the support and inspiration given by the author's best friends.

Authors' contributions: 1) The author conceived the idea and drafted the manuscript, 2- Professor reviewed and edited the work and 3) performed the paper's analysis.

Fundings. The research is funded solely by the university at which the author is based.

Ethics approval and consent to participate: Not applicable.

Consent for publication: Not applicable.

Availability of data and materials: The data sets for the present study are available electronically and publicly. World stock exchange and wards database.

Competing interests: The author declares no competing interests.

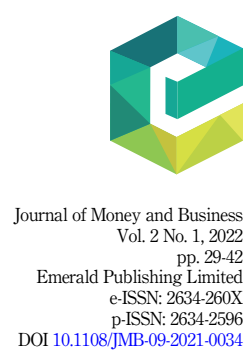




\begin{tabular}{lll} 
JMB & LTD & Long -term-debt \\
2,1 & STD & Short-term-debt \\
& IV & Independent variables \\
& DV & Dependent variables \\
& LN & Long term assets \\
& TX & Taxes \\
$\mathbf{3 0}$ & PT & Profitability \\
\hline & TA & Tangible assets \\
& NC & Net cash \\
& VIF & Variance inflation factors \\
& USA & United States of America
\end{tabular}

\section{Introduction}

Capital structure is the mixture of debt and the firm's performance elements used for its capitalization. The present study inspects the importance of equity structure company performance of G-7 most developed industrial country in the world. Most developed countries are (UK, US, France, Germany, Italy, Canada and Japan) main purpose of $G-7$ is to solve the international economic and monetary issues. In 1970, the leaders of UK, US, France, West Germany and Japan informally discussed the oil crisis and recession. The president of France, Valery Giscard, invited the leaders of these countries and Italy in 1975 for discussion of further issues about oil on a global level. Therefore, the next year Canada also joined these countries. In 1999, through FSB (financial stability forum) to managing international level monetary problems.

There is a general view about the effect of debt on firm performance that is vague. Several studies find a positive or no relation (Azeez, 2015; Walaa Wahid, 2007); on the other hand, some have a negative association (Chen, 2004; Saeedi, 2011; Salawu, 2007). Capital structure theory suggests that the firm determination refers to debt level, which is based on different trade-offs between debt and equity. The contemporary theory of capital structure was the earliest established MM theory in 1958. Enormous theoretical literature developed on Modigliani and Miller (1958), which escorts the formulation of alternative approaches acting as peking order theory, marketing timing theory, agency cost theory and trade-off theory.

Trade-off theory put forward the capital structure and leverage level ratio, balancing the back and forth between profits along with debt. Following the approach, Myers (1984) explains tax shield and deficit equal to a present value of the financial distress. The study of Porta and Florencio (1997) describes external financing needs for growing firms and equity financed. Debt finance is most common for firms with tangible assets (TA) (Rajan and Zingales, 1995). This research's principal goal was to examine the association of debt and assets structure determinants of industry corporations in G-7.

The latest study of (Kruk, 2021) explains the concept of capital structure and examines the techniques in classifying this structure. Furthermore, the analysis (Mavruk and Sjögren, 2021) describes local owners' capital structure and monitoring. Similarly, the study of (Mardones and Cuneo, 2019) finds a positive relationship between firm performance and capital structure. Additionally, the work of (Singh 2019) examines the effect of capital structure on profitability (PR). The number of forgoing studies about the determinants of capital management describes the debt level with different approaches. However, we captive that some studies enhance the analysis by using the zippy technique. The vigorous process is not a new approach to study capital structure. It is already used in forging studies (Taggart, 1977). The present studies also use this approach (Hovakimian and Li, 2011; McMillan and 
Camara, 2012; Öztekin and Flannery, 2012; Dang et al., 2014). Although we observe that the study of the firm's level is less in developed industry countries (G-7). Past researchers have a practically enrapt capital structure in developed and developing countries. They are currently concentering on the capital management behavior of firms operating in developed industries. These industries' markets have various features differentiated to developed one and effect market structure possibility.

By using the data of G-7 industry in developed country, we look for answers of the following questions? What are the determinants of capital structure? What are the effects of capital structure enticement on debt level? The main objective of this study is about capital structure companies listed on the G-7 stock exchange. We use the time-series panel data model to meet G-7 listed firms' theoretical and empirical results. We use descriptive summary, correlation and generalized method of moments (GMM) to analyze capital position determinants and debt level for different result analysis. In this article, the author has tried to explain the elements of capital formation determinants such as PR, assets tangibility, net cash (NC), taxes (TX) and long-term assets used in this study. Some previous empirical studies like Wessels (1988) in USA and Rajan and Zingales (1995) in G-7 countries. Another study in developing countries by Booth et al. (2001).

This paper's firm characteristics variables were empirically examined with the connection of debt level and performance of listed firms of G-7 throughout 2007 to 2018 utilizing the panel data accounting-based measure of TD, LTD and STD. In this paper, the first positive connection between PR, NC, assets tangibility, long-term assets and TX with TD, LTD and STD have been discussed. According to trade-off theory, capital management is set on by trade-off between firm characteristics variables and debt to analyze the firm performance outcomes. In this article, the author has used some limitations; there is no use of macroeconomic factors and primary data variables like as survey. Only secondary data were analyzed. The next part describes the detailed literature review, and Section 3 explains the data. Section 4 explains the methodology and analysis of the proposed IV and DV. Section 5 discusses the results and section 6 presents the remaining part of the study, like summary and implications and future extensions.

\section{Literature review}

The literature review helps create a structure for the study by pointing out the important matter in capital structure and its theories to the related article. The primary objective of this study is to test the connection between joining debt and firm performance theoretically; our assessment of the literature review will be a cornerstone on work around this zone. Various forgoing articles have described the connection between allying debt and firm operation. Numerous previous studies (Abor, 2005; Ruland, 2005; Robb and Robinson, 2014; Tayyaba, 2013) found a pragmatic relationship between indebtedness and firm staging. Additionally, another study Robb and Robinson (2009 has a significant relation of debt with firm performance. The article of Modigliani and Miller (1958) and Jensen (1986) also declare a positive association between debt and PR. On the other hand, some earlier reports have a negative relation with debt and no significant connection with firm performance. The study (Fama and French, 1998) describes debt generating agency problems without association with leverage and PR.

Kinsman and Newman describe various important reasons and alliances connecting appreciation and company achievement. Among these causes 1) Specific firm right decisions for the debt level to clarify the influence of insolvent on firms' effecting. 2) Shareholders and managers may have various attention the respective power of any particular achievement of obligation on firm performance must be familiar. 3) Necessary structure and firm

performance

31 
JMB 2,1

cause to study the liability and firm staging explain the interconnection joining debt level and shareholders substance.

Correspondingly, previous articles disclose conflicting outcomes regarding debt level benefits across the country (Wald, 1999; Frank and Goyal, 2003; Phillips and Sipahioglu, 2004; Lin and Chang, 2011; Berger and Bonaccorsi di Patti, 2006; Yazdanfar and Ohman, 2015). Additionally, several old studies report a positive connection with debt level and profit (Ruland and Zhou (2005); Jensen (1986); Berger and Bon Accorsi di Patti (2006), (Margarites and Psillaki, 2007); on the other hand, some articles narrate negative relation with leverage and profit. According to these essays (Campello, 2006; Weill, 2008; Pattitoni et al., 2014; Bae et al., 2017), there is an irregular connection between capital management and firm performance in the country.

The capital management of the corporation could be described by trade-off theory. According to trade-off theory, capital structure balances the various advantages to cost linked with debt funding. Debt assists include saving (tax shield) induced by the tariff-free interest expense from the corporation's pre-tax income. This theory also recounts the choice of debt ratio, which sums up the financial structure outcome from trade-off between debt and expenses tax benefits. This structure is familiar to static trade-off theory. A few writers expand this structure and promote the trade-off theory. It suggests that corporations may diverge from their debt level by adjusting costs and issuing the cost of debt and equity. We mention these conditions (Marsh, 1982; Sheel, 1994; Tim opler rohan williamson 1999), who explained capital structure adjustment to a long-run debt level.

According to some antecedent empirical work, no significant relationship has been found between debt level and capital structure in 2004 (Philips et al.). Therefore, another article (Walaa Wahid, 2007) talks about how debt level and equity do not affect the firm's performance. There are several previous studies told (TD, STD and LTD) has a positive link with firm measured by Abor (2005), Saeedi (2011) and Saeedi (2011). In developing countries, advanced research (Balakrishnan and Fox, 1993; Majumdar and Chhibber, 1999; Gleason et al., 2000; El-Sayed Ebaid, 2009; Foong and Idris, 2012; Varun Dawar, 2014) notice that leverage has negative relation with firm value. On the other hand, some studies revealed mixed analysis regarding debt and firm measured by (Cuong, 2016; Jaisinghani and Kanjilal, 2017; Le and Phan, 2017). A study of Rajan and Luigi Zingales (1995) write about international data which provide a unique opportunity for results.

The findings explained that capital structure has a significant relation with assets and no relation with profit (Qamar et al., 2016) endeavor to examine the predictors of external financing by spoiling the panel facts of Pakistani 304 nonfinancial companies enrolled on the stock exchange of Pakistan. Additionally, the study of Zerriaa and Noubbigh (2015) investigated the finance structure determinants in registered corporations in Tunisia, too, discovered tangibility has a pragmatic relationship with debt.

\section{Firm performance variables}

\section{LN assets}

The study (Fama and French, 2002) proclaims a positive association between LN assets and leverage level. Some prior studies found a significant relation with debt (Jong et al., 2008; Deesomsak et al., 2004; Eriotis et al., 2007). Similarly, the study of (Tong and Green (2005) investigated LN assets and leverage are positively correlated. Moreover, some forgoing analyses (Ahmed Sheikh and Wang, 2011; Ahmad et al., 2015) positively correlate with long-term resources and liabilities. Furthermore, the trading belief with the empirical results reported in Gropp and Heider (2010) have a positive link between LN assets and debt level. 
Taxes

The review of recounts tax should be positively associated with debt level. Therefore, in the trade-off theory, corporations choose debt financing because debt is tax-exempt. This tax benefit of debt allows the corporation to acquire more tax rates. In addition to the survey of Pettit and Singer (1985), portable ventures are less likely to post-high surplus with tax benefit. In addition, the evaluation of Bates and Kahle (2009) relates the opposing alliance of financial leverage and TX. The number of old research shows no significant link between TX and debt level (Afza and Hussain, 2011; Irfan, 2011).

\section{Profitability}

Some prior research (Hovakimian et al., 2004) spell out companies with high profits could have high debt. Moreover, (Hovakimian et al., 2001) PR allows the corporation to have more beneficial assets and taller debt. Further, the investigation of Dalci (2018) leverage impact on PR is explained by a U-shaped correlation allying profit and debt; therefore, another article (Evgeny, 2015) shows positive influence of leverage on firm performance. Similarly, the work of Lavorskyi (2013) examines long-term liabilities are more dominant because the non-current penalties would be considered a tool of manager's discipline.

\section{Tangible assets}

Furthermore, the work of Bharath and Pasquariello (2009), also describes TA have a significant association with debt. Similarly, some earlier research (Rajan and Zingales, 1995; and Ozkan, 2002) shows a strong connection with leverage and assets tangibility. Therefore, another survey Myers (1977) and Booth et al. (2001) explained that the debt level expands TA. In addition, some past studies (Hall and Nicos, 2004; Michaelas et al., 1999; Harris and Ravi, 1990) have examined that when the firms have more TA, investors should be more ready to extend term credit and leverage should be higher.

\section{Net cash}

A few previous analyses (Opler and Williamson, 1999; John and John, 1993) report that corporations which are less financially secure hold more cash, and have less debt. Besides, the evaluation of Graham and Harvey (2001) and Brounen et al. (2006) also recounts the financial solidity of cash. Additionally, there are some prior studies (Bates and Kahle, 2009; Duchin, 2010; Dittmar and Mahrt-Smith, 2007; Mulligan, 1997; Harford et al., 2008, 2014; Almeida, 2004) have examined that the LTD ratio gradually changes due to economic factors, and corporations increase their cash.

\section{Research method}

The current research is a factual analysis of antecedents of debt of listed companies in G-7 countries with the most up-to-date obtainable data. It is a descriptive study and has used a computable technique. A specimen of top 167 industry firms were rent on the basics of their promote capitalization and secondary information alliance via monetary evidence were gathered from their 12-month reports. Data collected of the selected corporations were from year 2007 to 2018, and chosen corporations were four or more years earlier used for analysis in this study. The specimen contains all manufacturing companies listed on a stock exchange in the G-7 industrial area, 167 companies are obtained with 2004 observations.

Multivariate least square method OLS regression is working on setting a connection between multiple explanatory variables (ln assets, PR, NC, TX, TA) and response variable (debt and its level). Data were reverted using E Views and Stata 13 software and results in regressions outputs were analyzed. Compound progressive is concluded of the basic regression paradigm. In a basic regression design, at most single predictor variable is 
$\mathrm{JMB}$ 2,1

available. However, there is more than one predictor of the response variables in multiple regressions. We notice from the previous studies that there may be more than one regressor variable of debt; in the current inquiry, various variables are used (see Table 1). Over and above mathematical problem, $b_{0}$ is the $y$-intercept, $b_{1}$ is the slope, and $X$ is regressor adaptable.

$$
\begin{aligned}
& y=b_{0}+b_{1} X \\
& y=b_{0}+b_{1} X
\end{aligned}
$$

Where $b_{0}$ is the seize of $y$ and $b_{1}$ and $b_{2}$ are the slant of $X_{1}$ and $X_{2}$.

$$
y=b_{0}+b_{1} X_{1}+b_{2} X_{2}+\ldots b_{k} X_{k}
$$

The various variables diverse regression model is given above.

$$
\begin{aligned}
\mathrm{TD}_{i t} & =\beta_{0}+\beta_{1} \mathrm{LA}_{i t}+\beta_{2} T_{i t}+\beta_{3} \mathrm{PT}_{i t}+\beta_{4} \mathrm{TA}_{i t}+\beta_{5} \mathrm{NC}_{i t}+\epsilon_{t} \\
\mathrm{LTD}_{i t} & =\beta_{0}+\beta_{1} \mathrm{LA}_{i t}+\beta_{2} T_{i t}+\beta_{3} \mathrm{PT}_{i t}+\beta_{4} \mathrm{TA}_{i t}+\beta_{5} \mathrm{NC}_{i t}+\epsilon_{t} \\
\mathrm{STD}_{i t} & =\beta_{0}+\beta_{1} \mathrm{LA}_{i t}+\beta_{2} T_{i t}+\beta_{3} \mathrm{PT}_{i t}+\beta_{4} \mathrm{TA}_{i t}+\beta_{5} \mathrm{NC}_{i t}+\epsilon_{t}
\end{aligned}
$$

In the above Eqs (4)-(6) the dependent variables (DV) are TD, LTD, and STD 0, and independent variables (IV) are LN (fixed assets), TX, PR, TA and NC), IT $i=$ firm and $t=$ time period, $\epsilon=$ error term.

\section{Results}

Results are shown in Tables $2-4$.

\section{Generalized method of moments}

Generalized method of moments (GMM) is shown in Tables 5-7.

\section{Discussions and results interpretation}

Table 2 shows the summary statistics of the IV and DV used in the current study. Table 1 presents the mean values for TD and LTD is 160.30 and 671.01, respectively, whereas the median values are 112.01 and 421.17 , respectively. SD (short-term debt) mean value is 936.12 , and the median of 535.23. The mean and median values of other capital structures, PR, NC, LA, TX, TA (556.51,125.02,131.11,408.8,116.01), respectively. On G-7 firms, the previous study (Rajan and Zingales, 1995) including developing countries research (Booth et al., 2001) about Chinese PLCs are not more highly levered firms in developing countries. A notable

\begin{tabular}{ll}
\hline Variables & Definitions \\
\hline TD & Total debt to assets \\
LTD & Long term debt to assets \\
STD & Short term debt to assets \\
LA & Fixed assets \\
TX & Taxes \\
PT & Profit after tax \\
TA & Tangible assets \\
NC & Net cash
\end{tabular}


difference between Chinese PLCs firms and developing countries is that both present a very low non-current liabilities ratio. There are some further surveys about LTD and STD is extremely low by Chen (2004), Huang and Song (2006) and Kasseeah (2008);

Table 3 reports the correlation between every pair of variables (IV and DV). The results clarify that TD, LTD, and STD compute are strongly positively or not correlated with LA, NC, PR, TA and TX) at 0.049,0.307,0.33.0.616 and 0.685 respectively. In the table, some variables have a high correlation with TD, LD AND SD. Thus, there are appear multicollinearity is an exit in the variables. We calculate the VIF for each variable to suggesting that multicollinearity is not a serious problem in the current study.

Table 4 shows the VIF test and indicates no multicollinearity between IV and DV. Therefore, even though there are relatively high correlations between some variables in Table 4, all variables can be used together for analysis.

\begin{tabular}{lcrrrrrrr}
\hline & LTD & \multicolumn{1}{c}{ TD } & \multicolumn{1}{c}{ SD } & PR & NC & LA & TAX & TA \\
\hline Mean & 671.01 & 160.30 & 936.12 & 556.51 & 125.02 & 131.11 & 408.8 & 116.01 \\
Median & 421.7 & 112.01 & 535.23 & 399.500 & 893.01 & 1164.5 & 129.02 & 629.50 \\
Maximum & 1.45 & 2.07 & 7.32 & 3.02 & 1.25 & 8.92 & 174.01 & 1.47 \\
Minimum & -3.21 & -423.03 & 1.95 & -3.15 & -1.49 & -299.01 & -429.02 & -10.01 \\
Std. Dev & 50.95 & 95.02 & 50.75 & 12.2 & 11.2 & 65.1 & 24.22 & 93.73
\end{tabular}

Note(s): TD (total debt), LTD (long term debt) STD (short term debt) LN (long term assets), NC (net cash), PR (profitability), TA (tangible assets) and TX (taxes)

Table 2.

Descriptive statistics

\begin{tabular}{lllllllll}
\hline & TD & LD & SD & LA & NC & PR & TA & TAX \\
\hline TD & 1 & & & & & & & \\
LTD & 0.939 & 1 & & & & & & \\
SD & 0.936 & 0.754 & 1 & & & & & \\
LA & 0.685 & 0.512 & 0.77 & 1 & & & & \\
NC & 0.049 & 0.049 & 0.042 & 0.199 & 1 & & & \\
PR & 0.307 & 0.222 & 0.353 & 0.104 & 0.143 & 1 & & \\
TA & 0.337 & 0.256 & 0.375 & 0.556 & 0.068 & 0.022 & 1 & \\
TAX & 0.616 & 0.39 & 0.765 & 0.693 & 0.107 & 0.335 & 0.377 & 1
\end{tabular}

Note(s): TD (total debt), LTD (long term debt) SD (short term debt) LN (long term assets), NC (net cash), PR (profitability), TA (tangible assets) and TX (taxes)

Table 3. Correlation matrix

\begin{tabular}{lc}
\hline Variables & VIF \\
\hline TD & 1.21 \\
LTD & 2.45 \\
STD & 2.40 \\
LA & 2.33 \\
NC & 1.90 \\
PR & 1.22 \\
TA & 1.92 \\
TX & 2.11 \\
Mean VIF & 1.94
\end{tabular}

Note(s): TD (total debt), LTD (long term debt) SD (short term debt) LN (long term assets), NC (net cash), PR (profitability), TA (tangible assets) and TX (taxes)

Table 4. Variance in factors (VIF) 


\begin{tabular}{|c|c|c|c|c|c|}
\hline \multirow{2}{*}{$\begin{array}{l}\text { JMB } \\
2,1\end{array}$} & \multirow[b]{2}{*}{ Variables } & \multirow[b]{2}{*}{ Coefficient } & \multirow[b]{2}{*}{ Std. Error } & \multirow[b]{2}{*}{$t$-Statistic } & \\
\hline & & & & & Prob \\
\hline \multirow{8}{*}{36} & LA & 0.877 & 0.034 & 25.192 & 0.000 \\
\hline & $\mathrm{NC}$ & 0.972 & 0.131 & 7.418 & 0.000 \\
\hline & PR & 1.607 & 0.127 & 12.564 & 0.000 \\
\hline & TA & 0.452 & 0.184 & 2.459 & 0.014 \\
\hline & TX & 6.241 & 0.869 & 7.181 & 0.000 \\
\hline & \multirow{2}{*}{$\begin{array}{l}\text { C } \\
\text { Mean Dep var } \\
\text { S.D Dep var }\end{array}$} & 2808 & 1458 & \multirow[t]{2}{*}{1.925} & \multirow{2}{*}{$\begin{array}{l}0.054 \\
0.552 \\
0.551\end{array}$} \\
\hline & & $\begin{array}{c}\text { Lovo } \\
16071536 \\
95273432\end{array}$ & 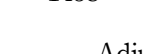 & & \\
\hline & \multirow{2}{*}{\multicolumn{5}{|c|}{$\begin{array}{l}\text { Note(s): LN (long term assets), NC (net cash), PR (profitability), TA (tangible assets), TX (taxes), Mean and } \\
\text { S.D(standard deviation) }\end{array}$}} \\
\hline $\begin{array}{l}\text { 1 able } \mathbf{S} \text {. } \\
\text { TD GMM results }\end{array}$ & & & & & \\
\hline
\end{tabular}

\begin{tabular}{lcccc}
\hline Variables & Coefficient & Std. Error & $t$-Statistic & Prob \\
\hline PR & 0.783 & 0.085 & 9.136 & 0.000 \\
NC & 0.368 & 0.087 & 4.194 & 0.000 \\
TX & 0.689 & 0.582 & 1.183 & 0.023 \\
TA & 0.138 & 0.123 & 1.124 & 0.026 \\
LA & 0.428 & 0.023 & 18.345 & 0.000 \\
C & 153 & 977 & 1.573 & 0.115 \\
Mean Dep var & 6710342 & $R$-squared & & 0.298 \\
S.D Dep var & 5095907 & Adjusted $R$ squared & & 0.297
\end{tabular}

Table 6. Note(s): LN (long term assets), NC (net cash), PR (profitability), TA (tangible assets), TX (taxes), Mean and S.D (LTD GMM results (standard deviation)

\begin{tabular}{lcccc}
\hline Variable & Coefficient & Std. Error & $t$-Statistic & Prob \\
\hline PR & 0.824 & 0.051 & 15.990 & 0.000 \\
TA & 0.314 & 0.074 & 4.232 & 0.000 \\
TX & 6.930 & 0.350 & 19.783 & 0.000 \\
NC & 0.603 & 0.052 & 11.435 & 0.000 \\
LA & 0.449 & 0.014 & 32.016 & 0.000 \\
C & 127 & 588 & 2.161 & 0.030 \\
Mean Dep var & 9361209 & $R$-squared & & 0.744 \\
S.D Dep var & 5075883 & Adjusted $R$-squared & & 0.743
\end{tabular}

Table 7.

STD GMM results

Note(s): LN (long term assets), NC (net cash), PR (profitability), TA (tangible assets), TX (taxes), Mean and S.D (standard deviation)

Tables 5-7, present the results of TD relation with other IV with the analysis of GMM-LN (long-term assets) has a statistically significant positive effect on TD under GMM $(\beta=0.877$, $p<0.000$ ). In the view of some prior studies (Jong et al., 2008; Deesomsak et al., 2004; Eriotis et al., 2007) associated fixed assets have a perfect connection with liability. Similarly, LN (fixed assets) has a complete connection alongside $\operatorname{LTD}(\beta=0.428, p<0.00)$ and $\operatorname{STD}(\beta=0.429, p<0.000)$. Fixed assets are long-term assets that a company has purchased and is using to produce its goods and services for company business volume enhance. 
$\mathrm{NC}$ has also applied positive association with debt level under $\operatorname{GMM}(\beta=0.972, p<0.000)$. $\mathrm{NC}$ is a figure that is reported on a company's financial statements. $\mathrm{NC}$ presents you how much capital you have on hand to continue operating the business. Cash is more important for day-today business operations. In parallel, $\mathrm{NC} 0$ has an effective relationship with LTD $(\beta=0.368, p<0.000)$ and $\operatorname{STD}(\beta=0.603, p<0.000)$. Therefore several previous inquires (Bates and Kahle, 2009; Duchin, 2010; Dittmar and Mahrt-Smith, 2007; Mulligan, 1997; Harford et al., 2008, 2014; Almeida, 2004) have investigated NC positive link between debt level.

$\mathrm{PR}$ has a positive interrelation with debt under $\operatorname{GMM}(\beta=1.607, p<0.000)$. Profit gives mangers a clear picture of the entire company, enabling them to strategize better and plan for growth. Profitability is a measurement of efficiency and success or failure. In the context of some prior work (Dalci, 2018; Evgeny, 2015; Lavorskyi, 2013) explained PR has a significant influence on debt level. Similarly, profit has a positive connection between $\operatorname{LTD}(\beta=0.783, p<0.000)$ and $\operatorname{SD}(\beta=0.824, p<0.000)$.

TA have a significant positive association with debt level under GMM $(\beta=0.452, p<0.014)$. TA are more important to a business because they show the company's worth. When a company shows worth with good documentation, the assets can serve as collateral for loans and make it easier for companies to get financing; they need to continue the business. Alliance with $\operatorname{LD}(\beta=0.138, p<0.026)$ and $\operatorname{SD}(\beta=0.314, p<0.000)$ TA has a positive association. Forgoing analysis (Rajan and Zingales, 1995; Ozkan, 2002; Bharath and Pasquariello, 2009) described TA have a unique link with leverage level.

TX also has a positive association with debt level under $\operatorname{GMM}(\beta=6.241, p<0.00)$. Tax planning strategies are typically employed to help a business achieve its financial and business goals. There are benefits of tax planning for both small and large companies. Tax pays for public goods and services; it is also a key element in the social contract between citizens and the economy. Some prior research (Bates and Kahle, 2009, Afza and Hussain, 2011; Irfan, 2011) has a significant connection between TX and debt level. In parallel, tax has a significant positive relation with $\operatorname{LTD}(\beta=0.689, p<0.023$ and $\operatorname{STD}(\beta=6.930, p<0.000)$.

\section{Conclusion}

This new study investigates a positive link between debt and firm functioning, utilizing evidence from 167 registered companies in G-7 countries over the period 2007 to 2018. We apply three measures of debt, total liabilities, non-current liabilities and current liabilities, including five measures of company power: PR, tangibility, TX, NC and fixed assets which are accounting performance measure. Furthermore the results disclose positive relationship between financial leverage (TD, LTD and STD) and firm performance measure (PR, TX, LA, $\mathrm{NC}$ and TA). While the trade-off theory is fully supported, our results (PR, TX, fixed assets, $\mathrm{NC}$ and TA) support the trade-off theory.

Finally, in the view of some past studies (McConnell and Servaes 1995; Stulz 1990) examined the positive link between firm performance and debt based on growth. The results of the present paper should be estimated in light of some limitations. First, this paper focuses on only listed manufacturing firms in G-7 countries. There, to work out anyhow, the outcomes can be generalizable. Future research must focus on the functioning other fabrication in G-7 countries. Second, ownership types are not considered inside research. Therefore the prospective study can be investigated ownership types and debt levels in developed industrial countries.

\section{References}

Abor, J. (2005), "The effect of capital structure on profitability: an empirical analysis of listed firms in Ghana”, Journal of Risk Finance, Vol. 6 No. 5, pp. 438-445, doi: 10.1108/15265940510633505. 
$\mathrm{JMB}$ 2,1

Afza, T. and Hussain, A. (2011), "Determinants of capital structure across selected manufacturing sectors of Pakistan”, International Journal of Humanities and Social Science, Vol. 1 No. 12, pp. 254-262.

Ahmad, N., Salman, A. and Firoz Shamsi, A. (2015), "Impact of financial leverage on firms' profitability : an investigation from cement sector of Pakistan”, Research Journal of Finance and Accounting, Vol. 6 No. 7, pp. 75-81.

Ahmed Sheikh, N. and Wang, Z. (2011), "Determinants of capital structure: an empirical study of firms in manufacturing industry of Pakistan”, Managerial Finance, Vol. 37 No. 2, pp. 117-133, doi: 10. 1108/03074351111103668.

Almeida, H. (2004), "The cash flow sensitivity of cash holdings", The Journal of Finance, Vol. 4, pp. 1777-1804, doi: 10.1111/j.1540-6261.2004.00679.x.

Azeez, A.A. (2015), "Corporate governance and firm performance: evidence from Sri Lanka”, Journal of Finance and Bank Management, Vol. 3 No. 1, pp. 180-189, doi: 10.15640/jfbm.v3n1a16.

Bae, J., Kim, S.J. and Oh, H. (2017), "Taming polysemous signals: the role of marketing intensity on the relationship between financial leverage and firm performance", Review of Financial Economics, Vol. 33, pp. 29-40, doi: 10.1016/j.rfe.2016.12.002.

Balakrishnan, S. and Fox, I. (1993), "Asset specificity, firm heterogeneity and capital structure", Strategic. Management Journal, Vol. 14 No. 1, pp. 3-16.

Bates, T.W. and Kahle, K.M. (2009), "Why do firm hold so much more cash.Pdf”, Journal of Finance, Vol. LXIV No. 5, pp. 1985-2021.

Berger, A.N. and di Patti, E.B. (2006), "Capital structure and firm performance: a new approach to testing agency theory and an application to the banking industry", Journal of Banking and Finance, Vol. 30 No. 4, pp. 1065-1102, doi: 10.1016/j.jbankfin.2005.05.015.

Bharath, S.T. and Pasquariello, P. (2009), "Does asymmetric information drive capital structure decisions ?”, The Review of Financial Studies, Vol. 22 No. 8, doi: 10.1093/rfs/hhn076.

Booth, L., Aivazian, V., Demirguc-Kunt, A. and Maksimovic, V. (2001), "Capital structures in developing countries", Journal of Finance, Vol. 56 No. 1, pp. 87-130, doi: 10.1111/0022-1082.00320.

Brounen, D., De Jong, A. and Koedijk, K. (2006), "Capital structure policies in Europe : survey evidence", Journal of Banking and Finance, Vol. 30, pp. 1409-1442, doi: 10.1016/j.jbankfin.2005. 02.010 .

Campello, M. (2006), "Debt financing: does it boost or hurt firm performance in product markets?”, Journal of Financial Economics, Vol. 82 No. 1, pp. 135-172, doi: 10.1016/j.jineco.2005.04.001.

Chen, J.J. (2004), "Determinants of capital structure of Chinese-listed companies", Journal of Business Research, Vol. 5712 SPEC.ISS, pp. 1341-1351, doi: 10.1016/S0148-2963(03)00070-5.

Cuong, N.T. (2016), "Threshold effect of capital structure on firm value: evidence from seafood processing enterprises in the south central region of Vietnam", International Journal of Finance and Banking Studies, (2147-4486), Vol. 3 No. 3, p. 14, doi: 10.20525/.v3i3.186.

Dalci, I. (2018), "Impact of financial leverage on profitability of listed manufacturing firms in China", Pacific Accounting Review, Vol. 30 No. 4, pp. 410-432, doi: 10.1108/PAR-01-2018-0008.

Dang, V.A., Kim, M. and Shin, Y. (2014), "Asymmetric capital structure adjustments: new evidence from dynamic panel threshold models", Journal of Empirical Finance, Vol. 19 No. 4, pp. 465-482, doi: 10.1016/j.jempfin.2012.04.004.

Dawar, V. (2014), "Article information : agency theory , capital structure and firm performance: some Indian evidence”, Managerial Finance, Vol. 40, pp. 1190-1206, doi: 10.1108/MF-10-2013-0275.

Deesomsak, R., Krishna, P. and Pescetto, G. (2004), "The determinants of capital structure: evidence from the Asia Pacific region”, Journal of Multinational Financial Management, Vol. 14 Nos 4-5, pp. 387-405, doi: 10.1016/j.mulfin.2004.03.001. 
Dittmar, A. and Mahrt-Smith, J. (2007), "Corporate governance and the value of cash holdings”, Journal of Financial Economics, Vol. 83 No. 3, pp. 599-634, doi: 10.1016/j.jfineco. 2005.12.006.

Duchin, R.A.N. (2010), “Cash holdings and corporate diversification”, Vol. LXV No. 3, pp. 955-992.

El-Sayed Ebaid, I. (2009), "The impact of capital-structure choice on firm performance: empirical evidence from Egypt", Journal of Risk Finance, Vol. 10 No. 5, pp. 477-487, doi: 10.1108/ 15265940911001385.

Eriotis, N., Vasiliou, D. and Ventoura-Neokosmidi, Z. (2007), "How firm characteristics affect capital structure: an empirical study”, Managerial Finance, Vol. 33 No. 5, pp. 321-331, doi: 10.1108/ 03074350710739605.

Evgeny, I. (2015), "The impact of financial leverage on firms performance", Corporate Finance Research, Vol. 9, pp. 24-36.

Fama, E.F. and French, K.R. (1998), “Taxes, financing decisions, and firm value”, Journal of Finance, Vol. 53 No. 3, pp. 819-843, doi: 10.1111/0022-1082.00036.

Fama, E.F. and French, K.R. (2002), "Testing trade-off and pecking order predictions about dividends and debt", Discovery Service for University of Fort Hare, Vol. 15 No. 1, pp. 1-33, available at: http://eds.b.ebscohost.com/eds/pdfviewer/pdfviewer?vid=0\&sid=9b4696d1-6c80-4689-ab7c50bf958413f7\% 40sessionmgr102.

Foong, S.Y. and Idris, R. (2012), "Leverage, product diversity and performance of general insurers in Malaysia”, Journal of Risk Finance, Vol. 13 No. 4, pp. 347-361, doi: 10.1108/ 15265941211254462.

Frank, M.Z. and Goyal, V.K. (2003), "Testing the pecking order theory of capital structure”, Journal of Financial Economics, Vol. 67 No. 2, pp. 217-248, doi: 10.1016/S0304-405X(02)00252-0.

Gleason, K.C., Mathur, L.K. and Mathur, I. (2000), "The interrelationship between culture, capital structure, and performance: evidence from European retailers", Journal of Business Research, Vol. 50 No. 2, pp. 185-191, doi: 10.1016/S0148-2963(99)00031-4.

Graham, J.R. and Harvey, C.R. (2001), "The theory and practice of corporate finance: evidence from the field", Journal of Financial Economics, Vol. 60 Nos 2-3, pp. 187-243.

Gropp, R. and Heider, F. (2010), "The determinants of bank capital structure", Review of Finance, Vol. 14 No. 4, pp. 587-622, doi: 10.1093/rof/rfp030.

Hall and Nicos (2004), "Determinants of the capital structures of European SMEs", Journal of Business Finance and Accounting, Vol. 31 Nos 5-6, pp. 711-728, doi: 10.1111/j.0306-686X.2004.00554.x.

Harford, J., Mansi, S.A. and Maxwell, W.F. (2008), "Corporate governance and firm cash holdings in the US”, Journal of Financial Economics, Vol. 87 No. 3, pp. 535-555, doi: 10.1016/j.jfineco.2007.04.002.

Harford, J., Klasa, S. and Maxwell, W.F. (2014), "Refinancing risk and cash holdings", Journal of Finance, Vol. 69 No. 3, pp. 975-1012, doi: 10.1111/jofi.12133.

Harris, M. and Ravi, A. (1990), "Capital structure and the informational role of debt", The Journal of Finance, Vol. 45 No. 2, pp. 321-349, doi: 10.1111/j.1540-6261.1990.tb03693.x.

Hovakimian, A. and Li, G. (2011), "In search of conclusive evidence: how to test for adjustment to target capital structure", Journal of Corporate Finance, Vol. 17 No. 1, pp. 33-44, doi: 10.1016/j. jcorpfin.2010.07.004.

Hovakimian, A., Opler, T. and Titman, S. (2001), "The debt-equity choice", The Journal of Financial and Quantitative Analysis, Vol. 36 No. 1, (Mar., 2001), pp. 1-24.

Hovakimian, A., Hovakimian, G. and Tehranian, H. (2004), "Determinants of target capital structure: the case of dual debt and equity issues", Journal of Financial Economics, Vol. 71 No. 3, pp. 517-540, doi: 10.1016/S0304-405X(03)00181-8.

Huang, G. and Song, F.M. (2006), "The determinants of capital structure : evidence from China”, China Economic Review, Vol. 17, pp. 14-36, doi: 10.1016/j.chieco.2005.02.007. structure and firm

performance 
$\mathrm{JMB}$ 2,1

Irfan, A. (2011), "Determinants of capital structure : empirical evidence from Pakistan", Vol. 67, available at: $\mathrm{http}: / / \mathrm{ssrn} . \mathrm{com} / \mathrm{abstract}=1977024$.

Jaisinghani, D. and Kanjilal, K. (2017), "Non-linear dynamics of size, capital structure and profitability: empirical evidence from Indian manufacturing sector", Asia Pacific Management Review, Vol. 22 No. 3, pp. 159-165, doi: 10.1016/j.apmrv.2016.12.003.

Jensen, M. (1986), "American economic association agency costs of free cash flow, corporate finance, and takeovers", American Economic Review, Vol. 76 No. 2, pp. 323-329.

John, T.A. and John, K. (1993), "Top-management compensation and capital structure”, The Journal of Finance, Vol. 48 No. 3, pp. 949-974, doi: 10.1111/j.1540-6261.1993.tb04026.x.

Jong, A.D., Kabir, R. and Thu, T. (2008), "Capital structure around the world : the roles of firm- and country-specific determinants Q", Journal of Banking and Finance, Vol. 32, pp. 1954-1969, doi: 10.1016/j.jbankfin.2007.12.034.

Kasseeah, H. (2008), "What determines the leverage decisions of Chinese firms?", Journal of the Asia Pacific Economy, Vol. 13 No. 3, pp. 354-374, doi: 10.1080/13547860802131334.

Kruk, S. (2021), "Impact of capital structure on corporate value - review of literature", Risk and Financial Management, Vol. 14 No. 155, pp. 2-13.

Lavorskyi (2013), "The impact of capital structure on firm performance: evidence from Ukraine", MA Thesis, Kyiv School of Economics.

Le, T.P.V. and Phan, T.B.N. (2017), "Capital structure and firm performance: empirical evidence from a small transition country", Research in International Business and Finance, Vol. 42 June, pp. 710-726, doi: 10.1016/j.ribaf.2017.07.012.

Lin, F.L. and Chang, T. (2011), "Does debt affect firm value in Taiwan? A panel threshold regression analysis", Applied Economics, Vol. 43 No. 1, pp. 117-128, doi: 10.1080/ 00036840802360310.

Majumdar, S.K. and Chhibber, P. (1999), "Capital structure and performance: evidence from a transition economy on an aspect of corporate governance", Public Choice, Vol. 98 Nos 3-4, pp. 287-305.

Mardones, J.G. and Ruiz Cuneo, G. (2019), "Capital structure and performance in Latin American companies capital structure and performance in Latin", Economic Research-Ekonomska IstraA3/4ivanja, Vol. 33, pp. 1-18, doi: 10.1080/1331677X.2019.1697720.

Margaritis, D. and Psillaki, M. (2007), "Capital structure and firm efficiency", Journal of Business Finance and Accounting, Vol. 34 Nos 9-10, pp. 1447-1469, doi: 10.1111/j.1468-5957. 2007.02056.x.

Marsh, P. (1982), "The choice between equity and debt: an empirical study", The Journal of Finance, Vol. 37, pp. 121-144, doi: 10.1111/j.1540-6261.1982.tb01099.x.

Mavruk, T. and Sjögren, S. (2021), "Capital structure and monitoring by local owners", Applied Economics, Vol. 53, pp. 4614-4631, doi: 10.1080/00036846.2021.1904127.

McConnell, J.J. and Servaes, H. (1995), "Equity ownership and the two faces of debt", Journal of Financial Economics, Vol. 39 No. 1, pp. 131-157, doi: 10.1016/0304-405X(95)00824-X.

McMillan, D.G. and Camara, O. (2012), "Dynamic capital structure adjustment: US MNCs \& DCs", Journal of Multinational Financial Management, Vol. 22 No. 5, pp. 278-301, doi: 10.1016/j.mulfin. 2012.10.001.

Michaelas, N., Chittenden, F. and Poutziouris, P. (1999), "Financial policy and capital structure choice in UK SMEs: empirical evidence from company panel data", Small Business Economics, Vol. 12 No. 2, pp. 113-130, doi: 10.1023/A:1008010724051.

Modigliani, F. and Miller, M.H.M.H. (1958), "American economic association corporate income taxes and the cost of capital : a correction", American Economic Review, Vol. 53 No. 3, pp. 433-443, doi: 10.1126/science.151.3712.867-a. 
Mulligan, C.B. (1997), "Scale economies, the value of time, and the demand for money: longitudinal evidence from firms", Journal of Political Economy, Vol. 105 No. 5, pp. 1061-1079, doi: 10.1086/262105.

Myers, S.C. (1977), "Determinants of corporate borrowing", Journal of Financial Economics, Vol. 5 No. 2, pp. 147-175, doi: 10.1016/0304-405X(77)90015-0.

Myers, S.C. (1984), “The capital structure puzzle”, The Journal of Finance, Vol. 39 No. 3, pp. 574-592, doi: 10.1111/j.1540-6261.1984.tb03646.x.

Opler, T. and Williamson, R. (1999), "The determinants and implications of corporate cash holdings", Journal of Financial Economics, Vol. 52, pp. 3-46.

Ozkan, A. (2002), "The determinants of corporate debt maturity: evidence from UK firms the determinants of corporate debt maturity: evidence from UK ${ }^{\circledR}$ rms", Applied Financial Economics, Vol. 12, pp. 19-24, doi: 10.1080/09603100110102691.

Öztekin, Ö. and Flannery, M.J. (2012), "Institutional determinants of capital structure adjustment speeds", Journal of Financial Economics, Vol. 103 No. 1, pp. 88-112, doi: 10.1016/j.jineco.2011.08.014.

Pattitoni, P., Petracci, B. and Spisni, M. (2014), "Determinants of profitability in the EU-15 area", Applied Financial Economics, Vol. 24 No. 11, pp. 763-775, doi: 10.1080/09603107.2014.904488.

Pettit, R.R. and Singer, R.F. (1985), “Agenda”, Financial Management Association, Vol. 14 No. 3, pp. $47-60$.

Phillips, P.A. and Sipahioglu, M.A. (2004), "Performance implications of capital structure: evidence from quoted UK organisations with hotel interests”, Service Industries Journal, Vol. 24 No. 5, pp. 31-51, doi: 10.1080/0264206042000276829.

Porta, R.L.A. and Florencio (1997), "Legal determinants of external finance", The Journal of Finance, Vol. 52 No. 3, pp. 1131-1150.

Qamar, M.A.J., Farooq, U., Afzal, H. and Akhtar, W. (2016), "Determinants of debt financing and their moderating role to leverage-performance relation: an emerging market review", International Journal of Economics and Finance, Vol. 8 No. 5, p. 300, doi: 10.5539/ijef.v8n5p300.

Rajan and Zingals (1995), "What do we know about capital structure? Some evidence from international data", The Journal of Finance, Vol. 50 No. 5, pp. 1421-1460, doi: 10.1111/j.15406261.1995.tb05184.x.

Robb, A.M. and Robinson, D.T. (2014), "The capital structure decisions of new firms", Review of Financial Studies, Vol. 27 No. 1, pp. 153-179, doi: 10.1093/rfs/hhs072.

Ruland, W. (2005), "Debt, diversification, and valuation", Review of Quantitative Finance and Accounting, Vol. 25, pp. 277-291.

Saeedi, A. (2011), "Capital structure and firm performance:evidence from Iranian companies", International Research Journal of Finance and Economics, Vol. 70, pp. 20-29, doi: 10.14453/aabfj.v1i4.3.

Salawu (2007), "An empricial analysis of the capital structure of selected quoted companies in Nigeria”, The International Journal of Applied Economics And Finance, Vol. 1, pp. 16-28, doi: 10. 3923/ijaef.2007.16.28.

Sheel (1994), "Determinants of capitals structure", Journal of Hospility and Tourism Research, Vol. 17, pp. 1-16, doi: 10.1177/109634809401700302.

Singh, N.P. (2019), "The effect of capital structure on profitability : an empirical panel data study", Business Research, Vol. 8, pp. 65-77, doi: 10.1177/2278682118823312.

Stulz, R.M.M. (1990), "Managerial discretion and optimal financing policies", Journal of Financial Economics, Vol. 26 No. 1, pp. 3-27, doi: 10.1016/0304-405X(90)90011-N.

Taggart, Jr (1977), "A model OF corporate financing decisions”, The Journal of Finance, Vol. 32 No. 5, pp. 1467-1484, doi: 10.1111/jofi.12597.

Tayyaba, K. (2013), "Leverage - an analysis and its impact on profitability with reference to selected oil and gas companies", International Journal of Business and Management Invention, Vol. 2 No. 7, pp. 50-59, available at: www.ijbmi.org. structure and firm

performance 
JMB

2,1

Tong, G. and Green, C.J. (2005), "Pecking order or trade-off hypothesis? Evidence on the capital structure of Chinese companies", Applied Economics, Vol. 37 No. 19, pp. 2179-2189, doi: 10.1080/ 00036840500319873.

Wahid, W. (2007), "Financial structure and firm value:empericial evidence from the United Arab Emirates", International Journal of Business Research, Vol. 7, pp. 69-76.

Wald, J.K. (1999), "How firm characteristics affect capital structure: an international comparison", Journal of Financial Research, Vol. 22 No. 2, pp. 161-187, doi: 10.1111/j.1475-6803.1999.tb00721.x.

Weill, L. (2008), "Leverage and corporate performance: does institutional environment matter?", Small Business Economics, Vol. 30 No. 3, pp. 251-265, doi: 10.1007/s11187-006-9045-7.

Wessels, T. (1988), "The determinants of capital structure choice", The Journal of Finance, Vol. 43 No. 1, pp. 1-19, doi: 10.1111/j.1540-6261.1988.tb02585.x.

Yazdanfar, D. and Öhman, P. (2015), "Debt financing and firm performance: an empirical study based on Swedish data", Journal of Risk Finance, Vol. 16 No. 1, pp. 102-118, doi: 10.1108/JRF-062014-0085.

Zerriaa, M. and Noubbigh, H. (2015), "Determinants of capital structure: evidence from Tunisian listed firms", International Journal of Business and Management, Vol. 10 No. 9, pp. 121-135, doi: 10. 5539/ijbm.v10n9p121.

\section{Corresponding author}

Muhammad Riaz can be contacted at: riazswl@hotmail.com

For instructions on how to order reprints of this article, please visit our website:

www.emeraldgrouppublishing.com/licensing/reprints.htm

Or contact us for further details: permissions@emeraldinsight.com 